\title{
Effects of the current land tenure on augmenting household farmland access in South East Ethiopia
}

Teshome Beyene Leta ${ }^{1 凶}$, Arega Bazezew Berlie ${ }^{2} \&$ Mehrete Belay Ferede ${ }^{2}$

According to the current land policy of Ethiopia, rural households are legally allowed to access agricultural lands. Nonetheless, the difficulty of rural population in accessing farmlands makes controversial authenticity of this land tenure to solve problems of household farmland access. This study aimed at assessing the effects of the current land tenure on augmenting household farmland access in Ethiopia. The study followed a mixed-methods research design to investigate the variables in the study. Thus, data were collected through a survey questionnaire, focus group discussion and interviews between May and June 2019. For data analysis, both descriptive and inferential statistics methods were employed. Consequently, study results indicated that the mean farmland size per household was 1.59 ha and government land allocation accounted for $41.9 \%$. The farmland accesses of households headed by persons below 35 years were $13 \%$ and that of all female-headed households was $23.2 \%$. It also showed that there were illegal farmland accesses via furtive farmland purchasing. On top of this, $63 \%$ of respondents perceived that the current land tenure was not a good rule. The regression analysis showed that the number of oxen, total crop production; annual income, education, and credit access were determinants of household farmland size. In conclusion, farmland scare areas in Ethiopia like Arsi zone have problems of deficient government land allocation, as well as unforeseen illicit farmland transactions. Given augmenting household farmland access, the study recommended that female-headed households have to be empowered and younger-headed households should be encouraged to enhancing their farmland accesses. The farming community should affirm to legal land regulations for maintaining their tenure arrangements. The local government should work according to land rules to liquidate illicit land markets. The national government should mitigate imbalanced farmland access by enforcing land rule acts such as land redistribution and reallocation with the consultation of the people. All level governments should strictly control alarming illegal changes of farmlands to urban areas by illicit land transactions.

\footnotetext{
${ }^{1}$ Department of Geography and Environmental Studies, Arsi University, Asella, Ethiopia. ${ }^{2}$ Department of Geography and Environmental Studies, Bahir Dar

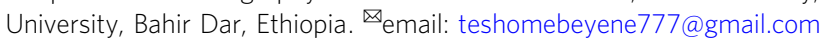




\section{Introduction}

and tenure is a key concept in land reform and influences measures given to improving land management (Chitsike, 2003). Bazga (2013) substantiates that land tenure studies are all to bringing into play the legal, social, economic, and political aspects of people. Differently, Simbizi et al. (2014) comment western-oriented economic approaches of land tenure issues do not ally with many tenure studies in developing countries' contexts. Holden and Ghebru (2016) confirm that their dissimilarities contribute to deviations in the field that makes land tenure studies more complex. Given that, this study was conceived to be done in Ethiopia mainly for the country suffers from the problem of rural households' farmland access. The problem seems that it resulted from the nation's enduring ambivalent land tenure transformations for a longer time till these days despite its larger agricultural population (Crewett and Korf, 2008).

Certainly, Ethiopia has experienced three successive land tenures since it emerged as a modern state in the late 19th century. These land tenures consisted of the Imperial regime's reigned to 1974, land tenure of the Derg military regime from 1974 to 1991, and the current land tenure since 1991 (Bodurtha et al., 2011). During the Imperial regime, Ethiopia had the rist tenure system in the northern and the gult lordship in the southern parts of the country (Teklu, 2004). The rist was a claim for kinship to have a share of common land and gult lords obtained lands in remuneration for military services. Indeed, the gult tenure system started to be distorted to become rist-gult a hereditary inheritance. Those Imperial regimes laws permitted rights of sale, exchange, transfer, and mortgage of private lands that facilitated smooth land access among few landowners (Gebregziabher and Holden, 2011).

Conversely, in southern Ethiopia, many farmers were reduced to abusive sharecropping arrangements under which landlords often demanded as much as $50 \%$ of yields in return for the right to practice subsistence farming on their lands (Rahmeto, 2009). That circumstance had resulted in deep grievance between the landless peasants. Thus, in 1974 popular revolution sought a radical change in the land tenure of the country (Jemma, 2004). Persuasively, the Derg regime land reform by 'Land to the Tiller' in February 1975 abolished prior all feudal land rules and made land the state property. The March 1990 policy revision of the same government eased previous restrictions. Thus, sharecropping, land transfer to legal heirs and hiring of labor were permitted although newly formed households' land access was possible only by employing intra-household land allocation (Ambaye, 2015).

The Derg land proclamation conveyed a bright future for free access to land for many landless peasants and tenants who had been deprived of the natural gift of their country. The law provided an opportunity for any person without discrimination who was willing to cultivate and to get rural land sufficient for maintenance. The size of land to be allocated for a household was made to be possibly equal up to the maximum of 10 hectares (ha) (Holden and Yohannes, 2002). However, all practices resulted in unforeseen outcomes such as farmland reduction and fragmentation by redistribution, eviction of the rural population by forceful villagization, the inefficiency of farmers cooperates, failure of agricultural productivity, and total poverty in the country dismissed the regime from power in 1991 (Kebede, 2002).

After the downfall of the Derg regime, the newly emerged transitional government under the Ethiopian Peoples' Revolutionary Democratic Front (EPRDF) announced the continuation of the land policy of the Derg regime with an amendment, and in 1995 state ownership of land was instituted in the new constitution (Deininger et al., 2004; Hagmann, 2006). The current land policy concealed earlier bans such as restrictions on land lease, labor hiring on a private farm, sharecropping, and individuals holding more than 10 ha. The rural land is accessed by government allocation, inheritance, gift, and land leasing, but cannot be sold, exchanged, or mortgaged (Bodurtha et al., 2011). The law allows for land expropriation and redistribution based on conditions such as unoccupied land, land with no heirs, and improper land management. Land redistribution and consolidation are pending on agreements of the community (Federal Democratic Republic of Ethiopia (FDRE), Proc. No. 456/2005; Oromia Region Council, Proc.No.103/2007).

The government claims that state ownership tenure prevents the concentration of land in the hands of few landowners by purchasing from poor misery peasants. On the other hand, propagators of privatization advocate land holding security and efficiency could not be secured (Ambaye, 2015). Besides, others comment that the national mean farmland size is comparatively small in the world (Paul and Gĩthĩnji, 2017). Concerning this, Sklenicka et al. (2014) show that some Central and Eastern European nations have 0.3 to 0.5 ha average farmland sizes. Similarly, Nachtergaele et al. (2011) and Wickramaarachchi and Weerahewa (2016) state that Asian nations also have 0.3 to 0.8 ha average farmland sizes. Indeed, African countries such as Congo 0.5 ha (Huggins, 2015), Rwanda 0.72 ha (Ali and Deininger, 2015), and Egypt 0.82 ha (Abdulmoneim et al., 2012) reveal small average national farmland sizes.

Accordingly, literature sources have shown that the current land tenure of Ethiopia could not solve the acute shortage of farmlands of the country. Rahmeto (2009) states that Ethiopia has a long agrarian history dating back to the ancient world where as currently $72.1 \%$ of the total farming households are operating on smaller than 1 ha land and the national average farmland size is about 0.8 ha. Similarly, Bodurtha et al. (2011) indicate that $43 \%$ of rural populations of Ethiopia are land less and $60 \%$ of which do not have sufficient farmland to produce adequate food for their own family. Paul and Gĩthĩnji (2017) also affirm that 54\% of the farmers survive on one hectare or less. The same writers add that the plots were broken into sub-plots leading to an average parcel size of 0.71 ha about extreme fragmentations.

Likewise, Headey et al. (2014) addressed that Ethiopia has 0.96 ha national average farmland size per household with variations among regions. Tigray, as well as Southern Peoples Regions each have 0.49 ha. Amhara Region has 1.09 ha and Oromia Region has the largest 1.15 ha per household. Commonly, in Ethiopia farmland is maintained according to the number of household sizes (Mengistu, 2014). Thus, during the last national land allocations of 1991 households were being allocated farmlands according to the number of their members of households. On top of this, the legitimacy of this land tenure remained controversial among sects in the field for a long time although the debate is influenced by ideological considerations rather than empirical data (Ambaye, 2015). Thus, assessing the effects of the current land tenure on augmenting household farmland access urges further studies.

Accordingly, this study endeavors to show the effects of this land tenure on augmenting households' farmland access and perceptional evaluation of these households on the current land tenure. The study was made in Arsi zone of Ethiopia where land redistribution was not even achieved during the last national land allocations. Supposedly, attention was given to agro-zones assuming that households' farmland access was believed to differ in disparities of agro-zones. Thus, investigators explored households' farmland sizes, factors affecting farmland access, and households' perception towards the legitimacy of land tenure. In such a setup, this study tries to fill the knowledge gap and to add empirical evidence partially missed in the field of the study of 
access of household farmland. The main objective of the study was to assess the effects of the current land tenure on augmenting household farmland access. It also endeavors to pursue specific objectives such as to survey household farmland sizes, to explore the legitimacy of current land tenure, and to categorize determinants of access of household farmland.

Conceptual framework. A review of literature in this study proves that various factors affect household farmland access in addition to the land tenure of the country. Supporting this idea, Mengistu (2014) states that old age farmers are in a position to have a larger total farmland than younger. Others substantiate that the extra number of oxen, education, annual income, and agricultural technologies used in farming moderate household

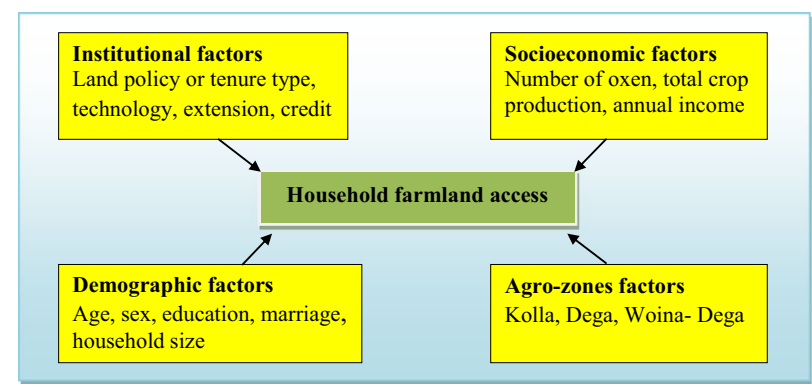

Fig. 1 The Schematic diagram of variables of household farmland access. Schematic diagram of variables showing the dependent variable (Green) and the predictor variables categorized as institutional, demographic, socioeconomic and physical factors (Yellow). farmland access (Abrha, 2015; Urgessa, 2015). Consequently, this study was structured on the cause and effect relationship framework of variables in the study as stated by Imenda (2014). The framework has interwoven factors explaining the relationships between the dependent and independent variables of this study. The dependent variable was household farmland access that was influenced by independent variables (Fig. 1).

\section{Materials and methods}

Context of the study area. The study was conducted in Arsi zone of Oromia Region in Southeast Ethiopia (Fig. 2). Arsi is located between $7^{0} 32^{\prime} 15^{\prime \prime} \mathrm{N}$ and $8^{0} 32^{\prime} 45^{\prime \prime} \mathrm{N}$, as well as $38^{0} 42^{\prime} 30^{\prime \prime} \mathrm{E}$ and $40^{0} 48^{\prime} 10^{\prime \prime} \mathrm{E}$. Asella town is the main center of the zone at $166 \mathrm{Km}$ South East of Addis Ababa the capital city. The zone has a total area of $20,982 \mathrm{Km}^{2}$ and accounts for $7 \%$ of the total area of Oromia Region (Arsi-Bale Road Development Project, 2005). Arsi zone's altitude ranges between $600 \mathrm{~m}$ above sea level (masl) and $4100 \mathrm{~m}$ asl. Thus, the zone experiences agro-zones of Kolla (tropical) 500-1500 $\mathrm{m}$ asl, Woina-Dega (sub-tropical) 1500-2300 m asl, Dega (temperate) $2300-3300 \mathrm{~m}$ asl, and Wurich (alpine) above $3300 \mathrm{~m}$ asl. The zone has a $12^{\circ} \mathrm{C}$ to $20^{\circ} \mathrm{C}$ annual range of temperature. It also receives bimodal rainfall occurring from March to April (short rainy season) and July to October (long rainy season). Its total annual rainfall reaches up to $800 \mathrm{~mm}$ in lowlands and over $1200 \mathrm{~mm}$ on highlands (Ministry of Agriculture, 1998; Meteorological Agency of Ethiopian, 2017).

According to Central Statistics Agency (CSA) 2015 data, the total population of Arsi zone in 1987 was 1,807,902, in 1994 grew to 2,217,245 and by 2015 reached to 2,637,657 of whom 1,323,424 were males and 1,314,233 females (CSA, 2015). The same data showed that $88.4 \%$ of the populations are agriculturalist consisting of $0.3 \%$ pastoralist. The dominant livelihood in the zone is subsistence agriculture of smallholder rain-fed farming.

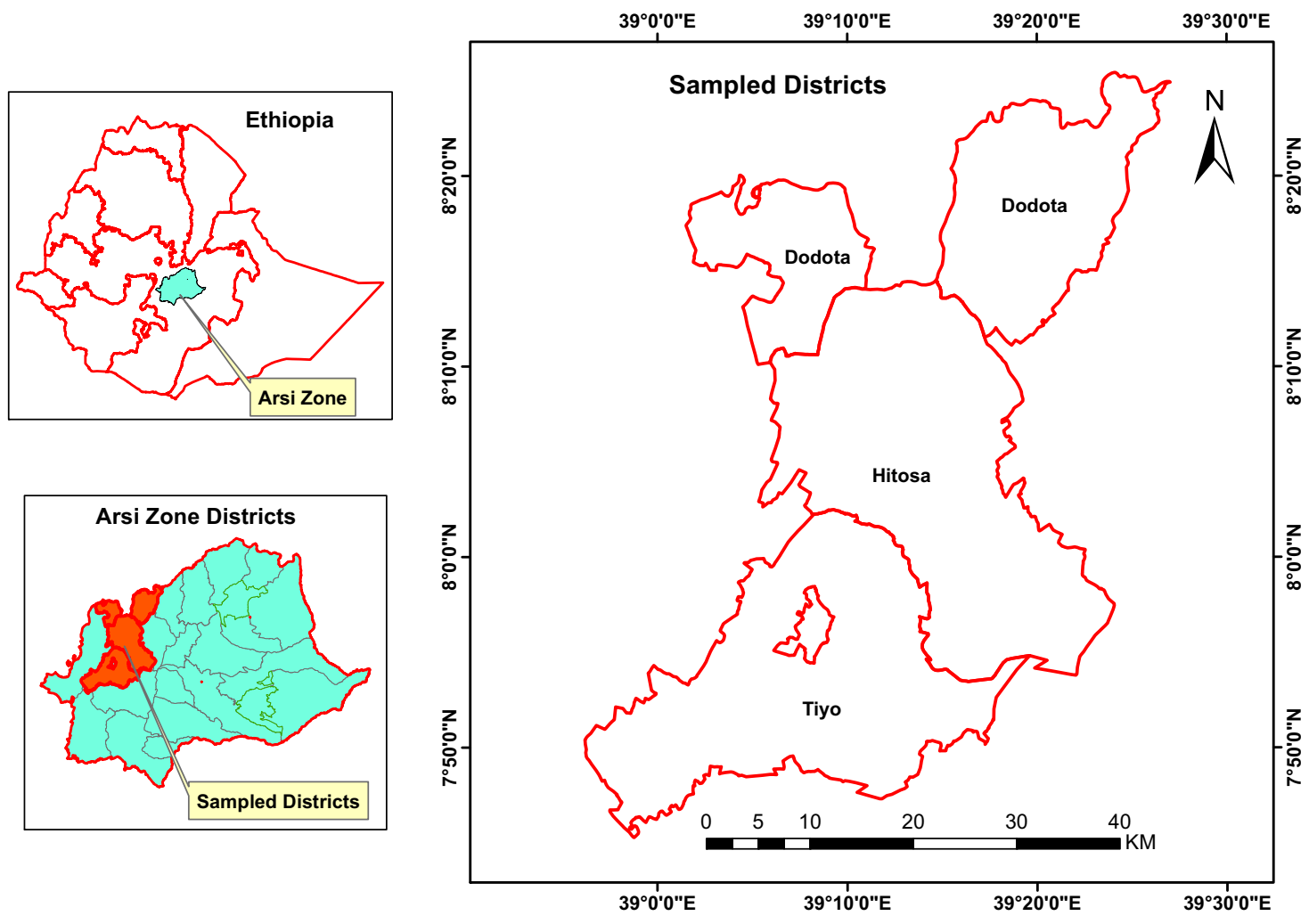

Fig. 2 Location map of the study area. Map of the study area showing location of Arsi zone (Beryl Green) in Ethiopia (White) and sampled districts Dodota, Hitosa and Tiyo (Fire Red) in Arsi zone (Beryl Green), as well as (White) in right side map. (Source of the data/shape file: Oromia Urban Plan Institute, 2018). 
As Mesay and Tolesa (2011) note, Arsi is known for cool weather crops production such as wheat (Triticum aestivum) and barley (Hordeum vulgare). The zone has promising transportation and trades where as industries are at infant stage most of which are privately owned manufacturing.

Research design. According to Merriam (2009), research design is accomplished by an investigator to decide on data collection, data analysis techniques, and data interpretation. Thus, in this study concurrent mixed methods research was employed to investigate variables of the effects of land tenure on augmenting household farmland access. The characteristics nature of those variables demanded to employ both quantitative and qualitative data types for making triangulation among the varied data sources. Indeed, the variables in this study emanated from demographic, socioeconomic, institutional and environmental factors of the sampled households. Consequently, concurrent mixed methods research was preferred to maintain triangulation among those data sources. Supporting this idea, Creswell (2013) addresses that in concurrent mixed method the researcher collects qualitative and quantitative data at the same time and converges both of them in order to provide comprehensive analysis of the research problem for the qualitative describes the process and quantitative shows the outcome.

Sampling techniques. This study employed multistage sampling techniques in selecting sampled households. Both the probability and the non-probability sampling techniques were applied. Initially, Arsi zone was purposively selected as the study area based on the researchers' prior knowledge of the problem. Currently, Arsi area is facing severe problems in household farmland access (Gudina, 2011; Begna et al., 2015). In this view, out of the 25 districts in the zone three (Dodota, Hetosa, and Tiyo) were purposively selected for meticulous reasons. On one hand, compared to others districts these show more problems in household land access (Gibson and Gurmu, 2012). On the other hand, they occupy adjacent land from the escarpment of the Great Rift Valley $600 \mathrm{~m}$ asl to tip of Chilallo Mountain $4033 \mathrm{~m}$ asl running for $100 \mathrm{Km}$ distance and covering $2417 \mathrm{Km}^{2}$ area. This has given the selected districts to show diverse agro-zones in the study that represent many parts of Ethiopia with similar agroecological zones.

Subsequently, from each of the three districts two rural kebeles (The lowest ruling units in the country) were randomly selected by lottery system. Totally six rural kebele administrations were selected from two heterogeneous sets of each kebele based on disparities of households' farmland access. For the validity of the procedures, this investigation acknowledges previous studies that achieved sampling with certain mechanisms in determining sizes of the sampled households. For instance, Abrha (2015) uses 400 sample households for $(N)=8640$, acceptable error $(e)=0.05$, alpha $(p)=0.01$ and $t=z=1.96$. Concurrently, sample size was computed in proportional size of each stratum as determined by using Kothari (2004) as shown below.

$$
n=\frac{Z^{2} p q N}{e^{2}(N-1)+Z^{2} p q}
$$

Whereas:

$n=$ sample size

$z=$ degree of confidence as value for selected alpha level

$p=$ precision of the population which is expected proportion of samples

$q=1-\mathrm{p}$ or variability value that is subtracted from precision of population

$N=$ population size, and $e=$ acceptable/margin of error
Consequently, constant value for $z$ at the significance level of $95 \%$ is (1.96), expected proportion of population is identified to be over $75 \%$ by study (Mengistu, 2014) which makes precision $(0.75)$ and variability $(0.25)$. The allowable error is $(0.05)$ and population consists of 5213 households in the study sites so that the computation shows:

$$
n=\frac{1.96^{2} \times 0.75 \times 0.25 \times 5213}{0.05^{2}(5213-1)+1.96^{2} \times 0.75 \times 0.25}=273
$$

Accordingly, the sampled households were pulled by systematic random sampling techniques from sample frames provided by kebele administrations. In line with this, Naing et al. (2006) advised that there must be a need for $10-20 \%$ of sample size to anticipate the return rate of the questionnaire and completeness of the information. As a result of this, adding up $15 \%$ of the calculated sample size in the formula 241 males and 73 females; Overall, 314 samples were employed in this study that makes $6.02 \%$ of the total population.

In addition to sampling for the survey, participants were communicated for qualitative data. These discussants were determined to participant in Focus Group Discussion (FGD) and Key Informant (KI) interviews. Thus, 36 participants in six FGDs one at each sampled kebele composed of six members were used. These six participants were agricultural development extension agent or worker (Commonly DA), two farmers, kebele administrator, women and youth leaders. In KI interview focus was given to prior experiences of the informants. Hence, eight KIs composed of administrators and heads of agricultural offices of sampled districts, as well as zone administration were included in the study.

Data collection and instruments. In this study, data were generated between May and June 2019 following the harvesting season of the study area for using the available time of sampled households. For the reason that this study employed a collection of both qualitative and quantitative data types, the major data collection instruments were survey questionnaire, FGD, and KIs interviews. In line with this, Bryman (2008) addresses that research data can be quantitative data in the report of words for events about the population under study and quantitative data that show numeric description about trends, attitude, or opinion of the population.

Questionnaire survey. Closed-ended questions were used in the survey on issues of households' demographics, socioeconomic, tenure systems, and land access. The questionnaire was pre-tested by a pilot survey supposed for correction of misconceptions in questions. Subsequently, the questionnaire was administered to respondents by a trained enumerator of DA in each kebele. Totally six enumerators were used to interview respondents door to door assisted by district agricultural experts and the investigator. Among the total of 314 households who participated in the survey, 310 (98.7\%) promptly responded to the questionnaire.

Qualitative data. The qualitative data were generated following the completion of the questionnaire survey. FGDs were designed on semi-structured guiding questions focused on trends of farmers' land access and perception of the legitimacy of current land tenure. Places were settled and each FGD was held for two hours. Similarly, KIs consisted of administrators and heads of agricultural offices of sampled districts, and the zone was interviewed on the realization of land access, gender balance, and landlessness. Totally 44 persons were employed for qualitative data. 


\begin{tabular}{|llll|}
\hline \multicolumn{2}{l}{ Table 1 Explanatory variables description, measurements } \\
and expected signs. \\
Variable name & Description & Measurements & Expected sign \\
\hline Sex & Dummy & 1. Male & + \\
& variable & 2. Female & \\
Age & Continuous & Number & - \\
Education & Continuous & Number & + \\
Household size & Continuous & Number & + \\
Number of oxen & Continuous & Number & + \\
Total production & Continuous & Number & - \\
Annual income & Continuous & Number & + \\
Access to credit & Dummy & 1. Yes & - \\
& variable & 2. No & \\
Evaluation of & Dummy & 1. Good & + \\
land tenure & variable & 2. Not good & \\
\hline
\end{tabular}

Data analysis techniques. The questionnaire survey was analyzed quantitatively by Statistical Package for Social Scientists (SPSS) soft ware version 22 and Stata version 15.1. The FGDs and KI interviews data were analyzed qualitatively by thematic analysis. Braun and Clarke (2006) substantiate that thematic analysis is a qualitative research method that can be used for identifying, analyzing, organizing, describing, and reporting the themes found within a research data set. Thus, descriptive and inferential statistics were employed. The Chi-square test was used to test tenure arrangements between sampled households by genders. One-way ANOVA was employed to test significant differences between mean values of farmland sizes among the agro-zones.

Besides, an econometric model was employed to estimate the regression of the total farmland sizes of sampled households. The regression model was employed to identify determinant factors of households' total farmland sizes. Thus, instead of using Ordinary Least Squares (OLS) estimation Hackman-two-stage sample selection model was employed to control the unconditional probability of predictor variables (Cameron and Trivedi, 2010). The model employed two independent variables namely household farmland access, a dummy variable with yes or no responses, and household total farmland size a continuous variable. The explanatory variables were presented in Table 1.Concurrently, findings were linked (mixed) in the result and discussion section by wringing first quantitative followed by qualitative results of the study.

Research ethical consideration. This study was conducted in a harmony with the universal and the Bahir Dar University, Ethiopia research ethical standards. The research proposal and assessment tools were submitted, as well as approved by the university's research body for complaints with its code of research ethics. Thus, researchers abstained from exaggerating the objectives and significances of this research for agitating the participants. Concurrently, as human participants were communicated for data sources priority was given to the dignity of the participants. Their genuine participation originated from their willingness to participate after understanding the academic value of the work. Consequently, focus group discussions' and key informant interviews' responses were recorded on the consents of the participants. Indeed, in writing the research result, anonymity of participants was ensured for confidentiality and privacies of the research participants.

\section{Result and discussion}

Farmland access and demographic characteristics. Results indicated that demographic characteristics of sampled households such as sex, age, marital status, household size, and education
Table 2 Households demographic characteristic.

\begin{tabular}{|c|c|c|c|}
\hline $\begin{array}{l}\text { Demographic } \\
\text { characteristic }\end{array}$ & Frequencies & Percentages & $\begin{array}{l}\text { Mean } \\
\text { farmland in ha }\end{array}$ \\
\hline \multicolumn{4}{|l|}{ Sex } \\
\hline Male & 238 & 76.8 & 1.62 \\
\hline Female & 72 & 23.2 & 1.50 \\
\hline Cumulative & 310 & 100 & 1.59 \\
\hline \multicolumn{4}{|l|}{ Age } \\
\hline $25-34$ & 40 & 12.9 & 1.12 \\
\hline $35-59$ & 241 & 77.7 & 1.60 \\
\hline $60-64$ & 11 & 3.6 & 2.00 \\
\hline $65-76$ & 18 & 5.8 & 2.26 \\
\hline Total & 310 & 100 & 1.59 \\
\hline \multicolumn{4}{|l|}{ Marital status } \\
\hline Married & 255 & 82.3 & 1.67 \\
\hline Single & 15 & 4.8 & 1.02 \\
\hline Divorced & 15 & 4.8 & 1.25 \\
\hline Widowed & 25 & 8.1 & 1.33 \\
\hline Total & 310 & 100 & 1.59 \\
\hline \multicolumn{4}{|l|}{ Household size } \\
\hline $1-4$ & 125 & 40.3 & 1.32 \\
\hline $5-8$ & 161 & 52.0 & 1.69 \\
\hline $9-13$ & 24 & 7.7 & 2.28 \\
\hline Total & 310 & 100 & 1.59 \\
\hline \multicolumn{4}{|l|}{ Education } \\
\hline $\begin{array}{l}\text { Cannot read } \\
\text { and write }\end{array}$ & 105 & 33.9 & 1.99 \\
\hline $\begin{array}{l}\text { Primary school } \\
(1-8)\end{array}$ & 174 & 56.1 & 1.45 \\
\hline $\begin{array}{l}\text { Secondary level } \\
(9-12)\end{array}$ & 31 & 10.0 & 1.03 \\
\hline Total & 310 & 100.0 & 1.59 \\
\hline
\end{tabular}

were affecting household farmland access. Age groups classification was made by taking minimum and maximum age values within the age distributions of respondents. It was categorized into productive age groups of respondents such as youth ages, adult ages and old ages. Accordingly, age groups were categorized in to 4 age classes. Household size was categorized in to 3 groups of family types such as small, medium and large families with considering manageable classes. Education level classification was made based on the general education classifications of the country. Thus, education level was divided in to 3 classes such as cannot read and write, primary and secondary school attendants as presented in Table 2. Accordingly, the sex composition data showed that the study area reveals $76.8 \%$ male-headed and $23.2 \%$ female-headed households.

As portrayed in Table 2, results affirmed that the total mean farmland size of the entire sampled households was 1.59 ha with the standard deviation of 0.83 . The mean farmland size for maleheaded households was 1.62 ha with the standard deviation of 0.88 and for female-headed household was 1.50 ha with the standard deviation of 0.63 . The KI interview results also pointed out that female household heads were rarely accessible to farmlands commonly via land gift and inheritance compared to their male counterparts.

Besides, a Pearson chi-square test was conducted to examine the association between gender and access to farmland. Gender was independent variable of dummy level as male and female. Farmland access was a categorical dependent variable of six levels such as government allocation, inheritance, gift, sharecropping, leased, and purchased. The Chi-square test between gender and farmland access showed statistically significant at $p<0.01$ $\left(\chi^{2}=56.36, \mathrm{df}=5, p=0.000\right)$. It indicated that the variables were dependent on each other and male heads were likely to be 
advantageous in access to farmland as shown in Table 3. The result was ascertained by comparison of male-headed households mean farmland 1.62 ha with female-headed households 1.50 ha average farmland size. The result matches with Mengistu (2014) that suggests in Arsi area rural households consist of $86 \%$ maleheaded and $14 \%$ female-headed households. It is also consistent with Mesele (2016) that supports in Ethiopia rural households are composed of $75 \%$ male and $25 \%$ female-headed households.

In addition, Table 2 presents that there were direct relationships between ages and farmland access as the data revealed that more farmlands were held by the higher age groups. Thus, the age group of 65 and above years held 2.26 ha mean farmland size compared to the 25-34 age group 1.12 ha mean farmland size. The FGD results supported the same results in which the discussants forwarded that in their respective kebeles land is in the hands of older peasants than the younger. The result is reliable with other studies made in Ethiopia. Bezu and Holden (2014a) show that farmers 18-29 years old accounts for $21 \%$ and $24 \%$ of rural landholding in Ethiopia and Oromia Region, respectively. Urgessa (2015) in his study in Ethiopia finds that old age farmers have more access to rural land.

Likewise, in Table 2 farmland access by marital status revealed that of all respondents' access to farmland were $82.3 \%$ married, $8.1 \%$ widowed, as well as $4.8 \%$ divorced and single each. Moreover, FGD substantiated that marriage would become a means of rural land access by land gift and inheritance. Similarly, household size was between 1 and 13 members and it established that farmland size per household was proportional to households' size. The Pearson correlation was positive $[r=0.32, n=310$, $p=0.000]$.The result is parallel to Paul and Gĩthĩnji (2017) that authenticate in Ethiopia rural households average family size is 5.27 per households working on 1.71 ha mean farmland. Similarly, as shown in Table 1, results confirmed that education status was inversely proportional to average farmland size. Pearson correlation was used to test association of farmland access and education. Thus, result explained that there was weak negative correlation between the two variables $[r=-0.37$, $n=310, p=0.001]$.

Farmland access and socio-economic characteristics. Given socio-economic characteristics, the study revealed that the distribution of farmland sizes showed a minimum of 0.2 ha, a maximum of $4.5 \mathrm{ha}$, and an average of 1.59 ha with a standard deviation of 0.83 . The result is smaller than the study made by

Table 3 Comparisons between genders on farmland access by tenure arrangements.

\begin{tabular}{|llll|} 
& Value & df & Asymp. sig. (2-sided) \\
\hline Pearson Chi-square & $56.357^{a}$ & 5 & 0.000 \\
Likelihood ratio & 56.997 & 5 & 0.000 \\
$N$ of valid cases & 310 & & \\
\hline
\end{tabular}

Begna et al. (2015) in Arsi zone in Ethiopia that addresses 2.65 ha total mean farmland size. Conversely, the result is higher than the study made by Headey et al. (2014) that state average farmland sizes for Ethiopia and Oromia Region is 0.8 ha and 1.15 ha, respectively. The result implies that households in the study area on average are working on larger than 1 ha of farmland. The majority of respondents $73.4 \%$ accessed less or equal to 2.0 ha of farmlands and the remaining percentage owned $2.01-4.50$ ha (see below Table 4).

As illustrated in Table 4, respondents who accessed 2.01 to 4.0 ha shared $25.6 \%$ and largely situated in the Kolla zone. Those who owned above 4.0 ha accounted for only $1 \%$ and were found in the Dega zone. The average farmland sizes for agro-zones were Kolla 1.78 ha, Dega 1.51 ha and Woina-Dega 1.46 ha. Supposed, those distinctions were explained by disparities in population density based on altitude set ups of agro-zones. The result is inconsistent with Mesay (2009) in a study made in Oromia Region in Ethiopia finds that Dega zone farmland size is larger than those of Kolla and Woina-Dega zones.

Besides, One-way ANOVA was used to test null hypothesis that states there is no significant difference in access to farmland between agro-zones. Thus, agro-zones were grouped to (Group1: Kolla; Group2: Dega; Group3: Woina-Dega) for test analysis as given in Table 5. As a result, One-way ANOVA test showed that there were significant differences in farmland sizes between agrozones at $p<.05$ level $[F(2,307)=4.70, P=0.010]$. Post-hoc comparisons using the Tukey test indicated that the mean score for Kolla $(M=1.78, \mathrm{SD}=0.80)$ was significantly different from both groups Dega $(M=1.51, S D=0.82)$ and Woina-Dega $(M=1.46, S D=0.85)$. Conversely, Dega and Woina-Dega did not show a significant difference from each other. Statistically, Kolla is greater than both Woina-Dega and Dega in farmland size by mean differences of 0.32013 and 0.27569 , respectively, and significant at $P<0.05$.

Likewise, the number of oxen owned by respondents established a diversified association with household farmland access. Thus, of the total respondents, $17.4 \%$ possessed no ox and held 1.20 ha average farmland and $65.8 \%$ possessed 1 to 2 oxen withholding of 1.55 ha farmland. Indeed, $15.2 \%$ owned $3-4$ oxen and held 2.14 ha farmland, as well as $1.6 \%$ owned 5-6 oxen and held 1.83 ha farmland. The relationship showed that higher farmland size was accessed by owners of a medium number of oxen. It attributed to households' livelihood options in which a small and large number of oxen owners engaged in non-farm livelihood strategies such as petty trading. The result is consistent with the finding of Tolossa (2005) substantiates that agriculture is directly influenced by the number of oxen as an extra number of oxen moderate production by contributing additional farmland access to the farming.

Moreover, the total crop production of respondents showed a minimum of 0 , a maximum of 258 , and a mean of 38.04 quintals per household. Of the total respondents, $2.3 \%$ did not produce any crop in the survey year 2018/2019 engaged in non-farm activities. $75.8 \%$ produced $1-50$ quintals, $20.3 \%$ produced $51-100$

Table 4 Households farmland access by agro-zones.

\begin{tabular}{|c|c|c|c|c|c|c|}
\hline Farmlands in ha & Kolla & Dega & Woina-Dega & Sum & Percentages & Mean farmland in ha \\
\hline $1.01-2.00$ & 51 & 62 & 36 & 149 & 48.2 & 1.4 \\
\hline $2.01-3.00$ & 30 & 7 & 20 & 57 & 18.3 & 2.36 \\
\hline $4.01-4.50$ & 0 & 3 & 0 & 3 & 1.0 & 4.35 \\
\hline Total & 108 & 100 & 102 & 310 & 100.0 & 1.59 \\
\hline
\end{tabular}


Table 5 Multiple comparisons between agro-zones by farmland size.

\begin{tabular}{|c|c|c|c|c|c|c|}
\hline (I) Agro-zones & (J) Agro-zones & Mean differ. (I-J) & Std. Error & Sig. & \multicolumn{2}{|c|}{$95 \%$ confidence interval } \\
\hline Kolla & Dega & $0.27569^{a}$ & 0.11408 & 0.043 & 0.0070 & 0.5444 \\
\hline \multirow[t]{2}{*}{ Dega } & Kolla & $-0.27569^{a}$ & 0.11408 & 0.043 & -0.5444 & -0.0070 \\
\hline & Woina-Dega & 0.04444 & 0.11568 & 0.922 & -0.2280 & 0.3169 \\
\hline Woina-Dega & Kolla & $-0.32013^{a}$ & 0.11350 & 0.014 & -0.5874 & -0.0528 \\
\hline
\end{tabular}

Table 6 Households tenure arrangements.

\begin{tabular}{|c|c|c|c|c|c|c|c|}
\hline Farmland size & Allocation & Inheritance & Gift & Sharecropping & Leased & Purchased & Total \\
\hline $0.02-1.00$ & 18 & 18 & 28 & 1 & 11 & 2 & 78 \\
\hline $1.01-2.00$ & 56 & 44 & 34 & 6 & 9 & 0 & 149 \\
\hline $3.01-4.00$ & 19 & 3 & 1 & 0 & 0 & 0 & 23 \\
\hline $4.01-4.50$ & 1 & 2 & 0 & 0 & 0 & 0 & 3 \\
\hline Frequencies & 130 & 80 & 70 & 7 & 20 & 3 & 310 \\
\hline
\end{tabular}

quintals, as well as $1.6 \%$ produced 101-258 quintals per households. Pearson correlation test corroborated that there was a medium positive correlation between farmland access and total crop production $[r=0.43, n=310, p=0.000]$. Similarly, annual income results demonstrated a minimum of 4900 Birr, a maximum of $166800 \mathrm{Birr}$, and an average of 36710 Birr. It established that $66.7 \%$ earned $10001-50000$ Birr, and only $1.6 \%$ earned more than 100000 Birr. The Pearson correlation coefficient indicated that there was a small positive correlation between annual income and farmland access $[r=0.25, n=310$, $p=0.000]$.

Furthermore, an independent t-test was conducted to compare annual income, as well as farmland sizes among on-farm and non-farm households. The test result indicated that there was a significant difference in annual income for on-farm households $(M=37781, \quad \mathrm{SD}=24274)$ and the non-farm $[(M=18252$, $\mathrm{SD}=11404 ; \mathrm{t}(308)=6.28, p=0.000]$. On top of this, the same test result also established a significant difference in farmland size for on-farm households $(\mathrm{M}=1.64, \mathrm{SD}=0.82)$ and the non-farm $[(M=0.69, \mathrm{SD}=0.45 ; \mathrm{t}(308)=8.46, p=0.000]$. Therefore, the results prove that larger farmland sizes yield more amount and higher annual incomes enable to access more farmland sizes. Indeed, small farmland size accessing households are engaged in non-farm livelihood mainly described as petty trading activities.

Farmland access and institutional characteristics. Recognized institutional factors, tenure arrangements practiced by the surveyed households in the study area showed major effects on the household farmland access. The sampled households mentioned that they were practicing mixed tenure arrangements such as government allocation, inheritance, gift, sharecropping, purchased, and land leased. In view of that, tenure arrangements of sharecropping and land leased were described to be commonly practiced by the respondents. However, the surveyed households reported on one dominant tenure arrangement for showing the effects of each particular tenure arrangement in the study area. In line with this, as compared to others tenure arrangements, the government allocation accounted for $41.9 \%$ and land purchased shared only $1 \%$ of the total tenure arrangements of the surveyed households as explained in Table 6 below.

As Table 6 shows, government land allocation accounted for maximum and benefiting older farmers having 52.2 years mean age. It is composed of $38.4 \%$ male and $3.5 \%$ female-head households, $56.9 \%$ owned less than 2.0 ha, and $43.1 \%$ accessed more than 2.0 ha. The result matches with the study of Hagos and Holden (2013) that affirm there is government allocation land scarce in Ethiopia. Inheritance was practiced by $12.6 \%$ of male and $13.2 \%$ of female-head households. It was the only land arrangement that favored female-head households. The result is consistent with Ege (2017) confirmed that many parents in Ethiopia favor dividing their farmland between their children whether or not that would be upheld by the court.

Besides, a land gift provided farmland access to $16.8 \%$ male and $5.7 \%$ female-heads aged between 26 and 55 with 38.87 years mean age. Conversely, FGD results established that there were furtive farmland transactions for life ages under land gift arrangement. The practice of secretive farmland transactions was proved in reality as land purchasing was reported to be only $1 \%$ compared to $22.5 \%$ land gift. About this, results addressed that land transactions were performed secretly with decisions on prices by land sellers, land buyers, and accompanies. Currently, farmlands cost between 200 and 1000 Eth. Birr per $1 \mathrm{~m}^{2}$ land. Once the furtive land transaction was completed kebeles would be communicated for legal land transfer to the buyer that could be maintained utilizing land gift between the beneficiaries.

Likewise, FGD results added that furtive land transactions were normally perceived and commonly practiced by the households particularly in urban surrounding areas. Indeed, kebele officials were blamed for their encouraging of land transactions with receiving certain amounts for legalizing illegal land transactions. Furthermore, variations were observed on land purchases in respect to the accesses of places to infrastructures such as road, 
irrigation and towns. Costs of farmlands also rely on proximity to those infrastructures and urban bordering farmlands were more expensive than others. The result is consistent with Teklu (2004) substantiates that population growth, infrastructures and agriculture with the overall rural economy growth favors expansion of land markets in Ethiopia in the future. Yiadom and Melesse (2014) also argue that city is not only acquiring more than lands it needs but also the alarming conversion of rural lands to urban is threatening agriculture in Ethiopia.

As given in Table 6, land lease accounted for $6.5 \%$ of the farmland access as practiced more by younger respondents aged between 25 and 50 years with 34.25 years mean age. Moreover, of the total land leases, male-headed accounted for households for $89.2 \%$, and female-headed shared only $10.8 \%$. Certainly, two forms of land lease practices were identified. That was proved by of all surveyed respondents $51 \%$ male-headed and $11 \%$ femaleheaded households land leased-in, as well as $6 \%$ male-headed and $3 \%$ of female-headed households land leased-out. The result matches with studies of Deininger et al. (2011) state that in Ethiopian land renters come from younger and more educated households. Ghebru and Holden (2015) also find that culture taboo forces female-heads more likely to lease out their land to male heads. Land leased-in proved scarcity of government land allocation and it was leased-out for lack of farm animals, physical inability to work, and scarcity of farm inputs

As it was also shown in Table 6, land sharecropping accounted for $2.3 \%$ of farmland access consisted of male-headed households aged 35 to 52 years. Of the total surveyed households sharecropping-in was practiced by $32 \%$ male-headed and $6 \%$ female-head households. Sharecropping-out was also attained by $6 \%$ male-headed and 3\% female-headed households. The FGD results substantiated gender discrepancies in sharecropping. FGD Participants addressed that female-headed households prefer to land contracts that do not result in conflicts so that female heads do not favor sharecropping for mostly it results in conflicts. The result matches with the study carried out by Deininger et al. (2011) in which results in a state that generally sharecroppers come from wealthier, younger, and more educated-headed households. Those households mainly rely on agriculture more than their counterparts.

Besides, sharecropping was accomplished to share yields among the sharecroppers based on agreements. Certainly, the land seeker would be access to farmland minimizing land scarcity to be available with farmland access. The landholders could escape the incapability of maintaining their farming activities that could be missed in the scarcity of farm inputs. Most importantly, sharecropping-out was accomplished by poor households for adverse factors such as lack of farm animals, physical inability to work, lack of seed, and other inputs. The result is consistent with Begna et al. (2015) point out that farmers sharecrop-in and sharecrop-out based on a financial provision of production costs and farming inputs on their farmlands that could be provided through sharecropping tenures. Furthermore, respondents suggested land redistribution $43 \%$, taking landless to land available places $29 \%$, and land reallocation $28 \%$ to be future strategies of the government to avoid scarcity of farmlands in the study area.

Farmland access and evaluation of current land tenure. Results on a perceptional evaluation of respondents on the current land tenure of the country indicated that a greater number of respondents did not have a good perception of the legitimacy of that land tenure. Certainly, of the total surveyed households $37 \%$ recognized that the current land tenure of Ethiopia was good and $63 \%$ perceived that it was not good tenure. Significant variations were observed between respondents by genders and ages on their perceptions of the legitimacy of the land tenure. Consequently, of the total respondents that perceived authenticity of the land tenure male-headed accounted for $75 \%$ and female-headed households shared only $25 \%$. This means that majority of female-headed households were not satisfied with the current land tenure and considered it is not good tenure.

Likewise, of the total respondents that perceived authenticity of the land tenure younger heads below total mean age or 45 -yearsold shared only $43 \%$ and those 45 and above years accounted for $57 \%$. This means that the majority of younger respondents regarded it as not good. Furthermore, of the total respondents that perceived authenticity of the land tenure those who held 1.01-2.00 ha accounted for only $50 \%$. This implies that half of the respondents of all farmland possessions regarded it as not good to augment farmland access. On the other hand, the existing land tenure was given recognition for it grants usufruct rights to farmers. Besides, FGD participants pointed out that household land access and tenure security are serious problems in their localities for visible disagreements over land contracts. KI interview results also addressed that there were gender imbalanced land access, tenure insecurity, and landlessness. Conclusively, results established that the current land tenure of Ethiopia has loose power in action although it is strictly lawful in public.

The result is different from the finding of Nega et al. (2003) that indicates the current land tenure of Ethiopia is perceived as good by 56 and $61 \%$ in the Oromia Region and the preposition "in" Ethiopia, respectively. It is also inconsistent with the study of Bodurtha et al. (2011) suggest that the current land tenure of Ethiopia is progressive although it needs amendments. Credibly, it matches with the result of Belay (2003) that comments on the longer time performance of current land policy show that it is not necessarily the best remedy for Ethiopia. Abdo (2013) reports review of the land policy of Ethiopia shows that the laws are quite vague in retention to the land certificate by smallholders and restitution of the land subject to lease at the end of the lease period that urges amendments in the current land policy of Ethiopia.

Econometric model result of household farmland size. A total of 9 variables were selected to estimate a regression of households' total farmland size with the Heckman-two-stage method as shown in Table 7 . The result of regression estimation showed that the probability of estimation established significant relationships between dependent and the selected explanatory variables at $P<$ 0.01 . Thus, out of the total predictors in the model, five were significant at 1 and $5 \%$ prob. levels. Indeed, the lambda $(\lambda)$ value showed the selectivity effect of predictor variables at a significant level hence, the model is fitted.

The regression estimation established that the number of oxen of households was positively correlated with total farmland sizes of households at $(p<0.01)$. The result implies that extra oxen allow accessing more farmlands. The result is consistent with the findings of previous studies. Tolossa (2005) finds that an extra number of oxen moderate production by contributing additional farmland access to farming. Baye (2017) addresses that in Ethiopia farm households mostly depend on oxen for plowing although the poor do not own an ox and the rich possess several oxen that make differences in farmland sizes.

Households' total crop production was positively and strongly correlated with their total farmland sizes at $p<0.01$. Synonymously, focus group discussions confirmed that increasing households' total crop production during a good harvest year strengthens the financial provision of households to access extra farmlands by various land contracts. The result implies that total crop production boosting improves household farmland sizes. 
Table 7 Heckman-two-step regression model for total farmland size estimation.

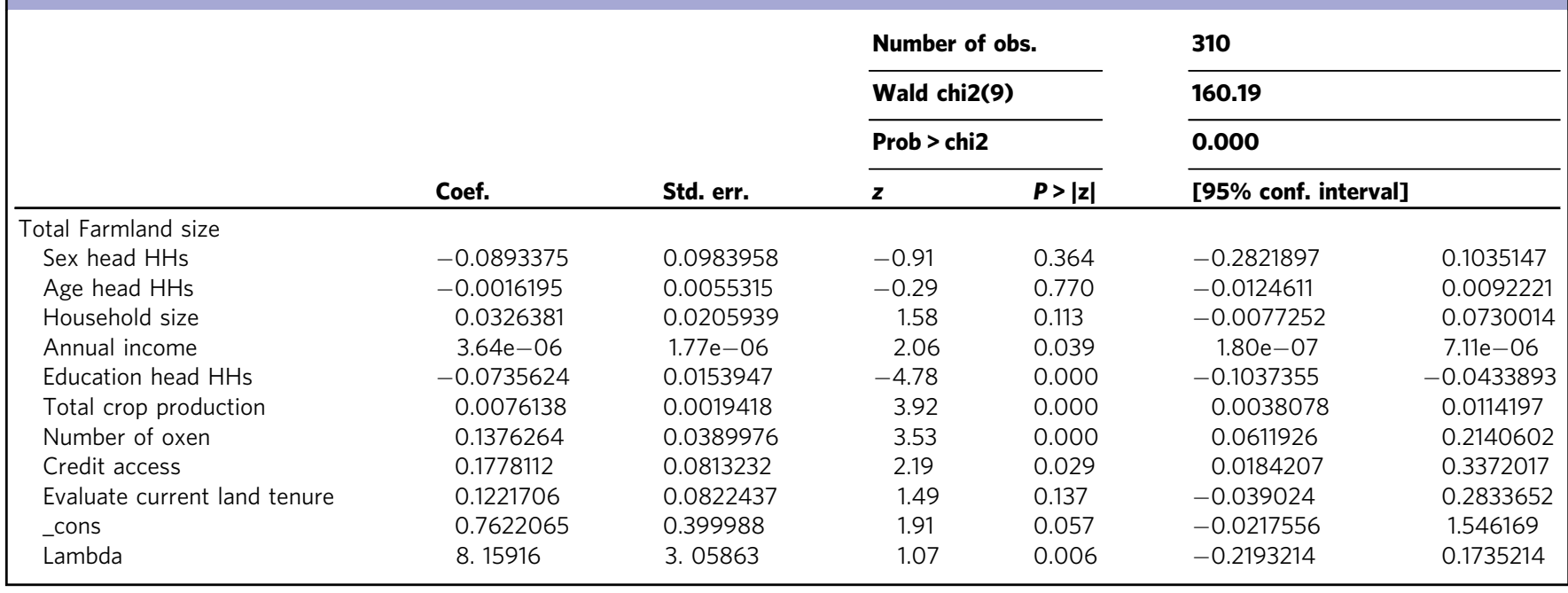

Previous studies in Ethiopia have reported comparable results that total crop production positively and significantly influences household farmland access (Gudina, 2011; Begna et al., 2015).

Households' education status as a variable captures the influence of literacy on household farmland access. In line with this, the education status of households was negatively and strongly correlated with their total farmland sizes at $p<0.01$. It was established that less literate households possessed more farmland sizes compared to the better educated. Here what should be realized is that literacy does not directly lead to small farmland sizes. However, the less literate farmers were able to access larger farmland sizes during previous land allocation. The finding evokes a similar result with Alemu et al. (2017) support that in Ethiopia farmers' literacy is negatively significant in association with households' farmland sizes.

Households' annual income was positively correlated with household total farmland sizes at $p<0.05$. The result is similar to the finding of a previously conducted study in Ethiopia. In line with this, de Brauw et al. (2013) find that rural households' annual income is assumed to affect household farmland access for it is hypothesized that better annual income improves production inputs. The same result was addressed by FGDs on the effects of income on households' farmland access. The discussants pointed out that income has much to play in affecting household farmland access by strengthening financial inputs to the farmers.

Access to credit was also positively correlated with respondents' total farmland sizes at $p<0.05$. The result was supported by the finding of Mengistu (2014) suggests that credit access facilitates rural households' financial provision to increase farmland access. Conversely, other variables together with household size a variable that was determining farmland access were not significant in this study. Thus, the study induces that household size is no more decisive factor in affecting household farmland access once the land allocation is maintained. The result is inconsistent with the preceding findings in Ethiopia. Bodurtha et al. (2011) and Ambaye (2015) address that Ethiopia has a trend of family size-based government land allocation in land reforms thus household size is a significant factor in farmland access.

\section{Conclusion}

The study area is situated in farmland scarce South East Ethiopian highland. The study addressed that household farmland accesses by sexes, ages, and agro-zones were imbalanced. The total mean farmland size of the study area was 1.59 ha with the male-headed households was 1.62 ha and the female-headed household was1.50 ha. The, 65 and above years age group held 2.26 ha mean farmland size compared to the 25-34 age group's 1.12 ha. Similarly, Kolla was greater than both Woina-Dega and Dega agro-zones in farmland size although Dega and WoinaDega did not show significant differences. The study also revealed that households' farmland accesses were $41.9 \%$ government allocations, $25.8 \%$ inheritance, and $22.5 \%$ gift. Indeed, it showed the existence of illegal land transactions through furtive land gifts.

Likewise, the study found that the current land tenure was recognized as little as an authentic rule for augmenting household farmland access. Thus, $63 \%$ of the total surveyed households perceived that the current land tenure of Ethiopia was not good. The regression model identified that number of oxen, household size, crop production, annual income and access to credit showed significant relationships with household farmland sizes. Therefore, the study recommended that female-headed households should be empowered by government to improve their farmland access. Younger-headed households should be encouraged by development institutions for promoting efforts to access farmland. The farming community should affirm to legal regulations for maintaining their tenure arrangements. The local government should work according to the land rule to liquidate illicit land markets. The national government should mitigate imbalanced households' farmland access by enforcing land rule acts such as land redistribution and reallocation with the consultation of people. All level governments should strictly control alarming illegal changes of farmlands to urban areas by illicit land transactions.

Limitations. Rural households' farmland access is a policy-related research topic that needs a longitudinal survey in repeated ways from various data sources. Nonetheless, this investigation was confined to one round household survey for multiple reasons. Above all, this survey was done under violations of peace and orders at the national level in general, and the study area in particular. Consequently, such inconvenience cast a shadow on getting encouraging the research environment to search for elongated data collection. Indeed, the investigation was confined to one round household survey mainly for time and financial constraints. 


\section{Data availability}

As it was detailed in the text datasets analyzed during this study came from public sources. These datasets were deposited to the journal by uploading the dataset and it is also available any time on reasonable request from corresponding author.

Received: 24 August 2020; Accepted: 7 January 2021;

Published online: 03 February 2021

\section{References}

Abdo M (2013) Legislative protection of property rights in Ethiopia. J Mizan Law Rev 7(2):165-206

Abdulmoneim A, Giselher K, Mohamed S (2012) Agricultural fragmentation of the nile delta; a modeling approach to measuring agricultural land deterioration in Egyptian Nile Delta. Procedia Environ Sci 14:79-97

Abrha B (2015) Factors Affecting Agricultural Production in Tigray Region, Northern Ethiopia. Dissertation, University of South Africa

Alemu G, Ayele Z, Berhanu A (2017) Effects of Land Fragmentation on Productivity in Northwestern Ethiopia. Hindawi. Adv Agric 2017:1-9

Ali D, Deininger K (2015) Is there a farm-size productivity relationship in African agriculture? Evidence from Rwanda. Land Econom 91(2):317-343

Ambaye D (2015) Land rights and expropriation in Ethiopia. Master thesis, Addis Ababa University. Springer

Arsi-Bale Road Development Project (2005) Atlas of Arsi-Bale Road Development Project. https://allafrica.com/stories/200412201093.html.

Baye T (2017) Poverty, peasant and agriculture in Ethiopa. Ann Agrarian Sci $15: 420-430$

Bazga B (2013) Responsible governance, land tenure and natural resources. Metalurgia Int 18(3):38

Begna B, Yami M, Lemma E, Solomom T, Etana T (2015) Characterization of crop production and marketing to improve food security in Arsi Zone, Ethiopia. J Agric Extens Rural Dev 7(4):87-97

Belay K (2003) Question regarding rural land ownership in Ethiopia. J Rural Dev 26:99-134

Bezu S, Holden S (2014a) Are rural youth in Ethiopia Abandoning agriculture? World Dev 64

Bodurtha P, Caron J, Chemeda J, Shakhmetova D, Vo L (2011) Land Reform in Ethiopia: Recommendations for reform. Document Prepared for Solidarity Movement.

Braun V, Clarke V (2006) Using thematic analysis in psychology. Qual Res Psychol 3:77-101

Bryman A (2008) Social research methods, 3rd ed. Oxford University Press Inc, New York

Cameron AC, Trivedi PK (2010) Microeconometrics Using Stata (Revised edition) Number Musr in Stata press books. Stata Corp LP., pp. 556-562

Central Statistical Agency of Ethiopia (CSA) (2015) Ethiopia Rural Socioeconomic Survey (ERSS) of Ethiopia. https://microdata.sca.org/index.php/catalog/2783.

Chitsike F (2003, December) A Critical Analysis of Land Reform in Zimbabwe. FIG Regional Workshop. Marrakech, Morocco. https://fig.net/resources/ proceedings/fig/morocco/proceedings/TS4/TS4_4_chitsike.pdf

Creswell J (2013) Qualitative inquiry and research design choosing among five approaches, 3rd edn. Sage Publications, California

Crewett W, Korf B (2008) Ethiopia: reforming land tenure. Rev Afr Polit Econ 35.116:203-220

De Brauw A, Mueller V, Woldehanna T (2013) Does internal migration improve overall well-being in Ethiopia?. Ethiopia Strategy Support Program II, 55

Deininger K, Ayalew D, Alemu T (2011) Productivity effects of land rental markets in Ethiopia: evidence from a matched tenant-landlord sample. World Bank Policy Research Working Paper Series, 2011

Deininger K, Jin S, Adnew B, Samuel G, Berhanu N (2004) Tenure security and land related investment: evidence from Ethiopia. Proceedings of the Conference on the Ethiopian Economy, Vol. II. Addis Ababa. Ethiopian Economic Association

Ege S (2017) Land tenure insecurity in post-certification Amhara, Ethiopia. Land Use Policy 64:56-63

Federal Democratic Republic of Ethiopia (FDRE) (2005) Proclamation of rural land administration and land use. Proclamation No. 456/2005. Negarit Gazeta. Year 11, No. 44. Addis Ababa. Ethiopia. Accessed 10 Dec 2018

Gebregziabher G, Holden ST (2011) Distress rentals and the land rental market as a safety net: contract choice evidence from Tigray, Ethiopia. Agric Econ 42:45-60

Ghebru H, Holden S (2015) Reverse-share-tenancy and agricultural efficiency: farm-level evidence from Ethiopia. J Afr Econom 24(1):148-171
Gibson M, Gurmu E (2012) Rural to Urban Migration is an Unforeseen Impact of Development Intervention in Ethiopia. PLoS ONE 7(11):e48708

Gudina D (2011) Farmland Fragmentation and Its Impact on Food Production in Highland Villages of Seru District, Oromia Regional State, South Eastern Ethiopia. https://pdfs.semanticscholar.org/9f14/7827cbecf5ce5c85c2247d4dbbca3568d3a0 pdf

Hagmann T (2006) Ethiopian political culture strikes back: a rejoinder to J. Abbink. Afr Affairs 105(421):605-612

Hagos, G, \& Holden, S (2013). Links between tenure security and food security: evidence from Ethiopia. Ethiopia Strategy Support Program (ESSP) II Working Paper 59, Ethiopian Development Research Institute (EDRI), IFPRI

Headey D, Dereje M, Taffesse A (2014) Land constraints and agricultural intensification in Ethiopia: a village-level analysis of high-potential areas. Food Policy 48:129-141

Holden S, Ghebru H (2016) Land tenure reforms, tenure security and food security in poor agrarian economies: causal linkages and researches. Global Food Security 10:21-28

Holden S, Yohannes H (2002) Land redistribution, tenure insecurity, and intensity of production: study of farm households in southern Ethiopia. Land Econ 78.4:573-90

Huggins C (2015) Land-Grabbing, Agricultural Investment and Land Reform in the Democratic Republic of Congo. Research gate. https://www.researchgate.net/ publication/5057151_Land_RedistributionTenureInsecurity-and_Intensity_of Production_A_Study_of_Farm_Households_in_Southern_Ethiopia

Imenda S (2014) Is there a conceptual difference between theoretical and conceptual frameworks? J Soc Sci 38(2):185-195

Jemma H (2004) The politics of land tenure in Ethiopian history: experience from the south. In: XI world congress of rural sociology. Trondheim, Norway, pp. $25-30$

Kebede B (2002) Land tenure and common pool resources in rural Ethiopia: a study based on fifteen sites. Africa Dev Rev 14:113-149

Kothari R (2004) Research methodology, methods and techniques. New Age International PLtd. publishers, New Delhi, India

Mengistu W (2014) Socio-Economic challenges of smallholder farmers in agricultural practice. In: Robe Woreda, Arsi Zone, Oromia Region

Merriam S (2009) Qualitative research: a guide to design and implementation, 2nd edn. Wiley Imprint, San Francisco

Mesay M (2009) Causes of rural household food insecurity: a case from Kuyu District, Central Ethiopia. J Sustain Dev Africa 11:286-304

Mesay Y, Tolesa A (2011) Baseline survey in selected wheat producing areas of Ethiopia: the case of Arsi zone, Eastern Africa Agricultural Productivity Program (EAAPP)

Mesele BT (2016) Rural Non-farm livelihood diversification among farming households in Saharti Samre Woreda, Southeastern Tigray. Dissertation, Addis Ababa University

Meteorological Agency of Ethiopian (MAE) (2017) Kulumsa First Class Meteorological Station. Official data, Spread sheet. Accessed 15 Dec 2018

Ministry of Agriculture (MoA) (1998) Agro-Ecological Zones of Ethiopia. Natural Resources Management and Regulatory Department. Addis Ababa, Ethiopia. Accessed 05 Dec 2018

Nachtergaele F, Bruinsma, J, Valbo-Jorgensen J, Bartley D (2011) Anticipated Trends in the Use of Global land and water Resources. SOLAW Background Thematic Report-TR01 http://www.fao.org/fileadmin/templates/solaw/files/ thematic reports/TR 01_web.pdf

Naing L, Winn T, Rusli B (2006) Practical issues in calculating the sample size for prevalence studies. Archives Orofacial Sci 1:9-14

Nega B, Adenew B, Gebre Sellasie S (2003) Current land policy issues in Ethiopia. Land Reform Land Settle Cooperat 11(3):103-124.

Oromia Region Council (2007) The amended Oromia Region Land Administration and Utilization proclamation. Pro. No.103, Finfinne. Accessed 10 Dec 2018

Oromia Urban Plan Institute (2018) Shape file GIS data for major features in Oromia region. https://www.ethyp.com/company/353529/OROMIA_URBAN_ PLANNING INSTITUTE

Paul M, Gĩthĩnji M (2017) Small farms, smaller plots: land size, fragmentation, and productivity in Ethiopia. J Peasant Stud 45:1-19

Rahmato D (2009) The Peasant and the State: Studies in Agrarian Change in Ethiopia, 1950s-2000s. Addis Ababa University Press, Addis Ababa

Simbizi MCD, Bennett RM, Zevenbergen J (2014) Land tenure security: revisiting and refining the concept for Sub-Saharan Africa's rural poor. Land Use Policy 36:231-238

Sklenicka P, Janovska V, Salek M, Vlasak J, Molnarova K (2014) The Farmland Rental Paradox: extreme land ownership fragmentation as a new form of land degradation. Land Use Policy 38:587-593

Teklu A (2004) Rural land, emerging rental land markets and public policy in Ethiopia. African Dev Rev 16(1):169-202

Tolossa D (2005) Rural livelihoods, Poverty and Food security in Ethiopia: A case study at Erenssa and Garbi communities in Oromia Zone Amhara Region. 
Doctorial Thesis Department of Geography, Norwegian University of Science and Technology (NTNU), Trondheim

Urgessa T (2015) The Determinants of Agricultural Productivity and Rural Household income in Ethiopia. Master Thesis, Addis Ababa University

Wickramaarachchi N, Weerahewa J (2016) Land fragmentation and land productivity: empirical evidence from land distribution schemes of Sri Lanka. J Bus Manag 5(1):11-21

Yiadom KS, Melesse A (2014) The impact of urban sprawl on the livelihood of fringe farmers in Mekelle, Ethiopia. Res Humanit Soc Sci 4(16):126-134

\section{Acknowledgements}

The authors are grateful to all participant respondents and data sources whose good willingness and patience in responding to questions made this study meaningful. The authors express their thanks to DAs at Rural Kebele Administrations and agricultural experts at district offices for supporting their enumerations. They are also indebted to Bahir Dar University, Ethiopia for funding financial grant for this study data collection.

\section{Competing interests}

The authors declare no competing interests.

\section{Additional information}

Supplementary information The online version contains supplementary material available at https://doi.org/10.1057/s41599-021-00709-w.
Correspondence and requests for materials should be addressed to T.B.L.

Reprints and permission information is available at http://www.nature.com/reprints

Publisher's note Springer Nature remains neutral with regard to jurisdictional claims in published maps and institutional affiliations.

(c) Open Access This article is licensed under a Creative Commons Attribution 4.0 International License, which permits use, sharing, adaptation, distribution and reproduction in any medium or format, as long as you give appropriate credit to the original author(s) and the source, provide a link to the Creative Commons license, and indicate if changes were made. The images or other third party material in this article are included in the article's Creative Commons license, unless indicated otherwise in a credit line to the material. If material is not included in the article's Creative Commons license and your intended use is not permitted by statutory regulation or exceeds the permitted use, you will need to obtain permission directly from the copyright holder. To view a copy of this license, visit http://creativecommons.org/ licenses/by/4.0/.

(C) The Author(s) 2021 